\title{
Quantification of Zerumbone in Eleven Accessions of Curcuma longa Using RP-HPLC
}

\author{
P. R. KSHIRSAGAR, N. V. PAWAR ${ }^{1}$, S. P. PATIL ${ }^{2}$, M. S. NIMBALKAR ${ }^{2}$ AND S. R. PAI ${ }^{3 *}$
}

Department of Biotechnology, Shivaji University, Vidya Nagar, ${ }^{1}$ Department of Botany, The New College, ${ }^{2}$ Department of Botany, Shivaji University, Vidya Nagar, Kolhapur-416 004, ${ }^{3}$ Amity Institute of Biotechnology (AIB), Amity University, Mumbai-Pune Expressway, Bhatan, Post Somathne, Panvel, Mumbai-410 206, India

Kshirsagar et al.: Zerumbone from eleven accessions of Curcuma longa

\begin{abstract}
Zerumbone has gained attention in cancer research due to its tumor suppressor potency. Present study aimed to investigate zerumbone content from eleven cultivars of Curcuma longa by reversed-phase highpressure liquid chromatographic analysis. The fresh and dry samples were subjected for the reversedphase high-pressure liquid chromatographic analysis of zerumbone including validation studies. Fresh samples revealed zerumbone content ranged from $0.383-2.179 \mathrm{mg} / \mathrm{g}$ while dry samples ranged from 3.209$8.333 \mathrm{mg} / \mathrm{g}$. Dry samples reflected high zerumbone content compared to fresh samples. Among the different cultivars accessed Selam showed highest content of zerumbone on fresh weight basis while, Alleppey on dry weight basis. This study provided comprehensive information on zerumbone content in members of family Zingiberaceae and also quantified it in eleven Curcuma longa cultivars from India.
\end{abstract}

Key words: Zingiberaceae, Curcuma, RP-HPLC, zerumbone

Zerumbone (IUPAC: 2,6,9,9-tetramethyl-[2E,6E,10E]cycloundeca-2,6,10-trien-1-one) is a sesquiterpene from the edible plant Zingiber zerumbet Smith. It suppresses various tumours in a potent manner ${ }^{[1]}$. Rahman et al. ${ }^{[2]}$ 
has reviewed and comprehensively listed anticancer properties of zerumbone. It possesses antinociceptive, antiinflammatory, antiulcer, antihyperglycaemic, immunomodulator and antiplatelet activities ${ }^{[2-4]}$. Zerumbone has been reported from different species of Curcuma, Alpinia and Zingiber from the family Zingiberaceae ${ }^{[2]}$. A range of variation in contents have been reported from 0.03 to $84.80 \%$ in the family (Table 1) ${ }^{[5-26]}$. It has been admitted that this differences in zerumbone content in the plants were not due to chemotypes ${ }^{[2,4]}$.

India is the largest producer of turmeric in the world (93.7 \% of the total world production), which is cultivated in 150000 hectares in India ${ }^{[27,28]}$. In this context, there is a need to study and identify high yielding chemotypes for economically viable genus Curcuma longa (family: Zingiberaceae) and its cultivars. Use of turmeric as blood purifier, antiseptic and even for plant has been well-documented for its wide range of pharmacological properties ${ }^{[29,30]}$. The species is chiefly studied for its phytoconstituents curcumin and its pharmacological properties ${ }^{[31-33]}$. Among the several other constituents present in the plant Gantait and coworkers ${ }^{[30]}$ reported presence of zerumbone in C. longa. Apart from this there are no reports of zerumbone from $C$. longa (Table 1). However, to the best of our knowledge, there have been no attempts to validate and quantify zerumbone content from C. longa cultivars from India, using reversed-phase high performance liquid chromatography (RP-HPLC) analysis.

The study intended to compile various reports on identification of zerumbone from members of zingiberaceae and to evaluate zerumbone content from eleven cultivars of $C$. longa (viz. Selam, Krishna, Tekur, Rajapuri, Phuleshwar, Prabha, Bawdhan, Pachwad, Alleppey, Kuchipudi and Rajampeth) with its validation using RP-HPLC method.

Eleven Curcuma longa cultivars were obtained from Indian Council of Agriculture Research (ICAR), Centre, Sangli, Maharashtra, India, labelled as CUR-A (Selam), CUR-B (Krishna), CUR-C (Tekur), CUR-D (Rajapuri), CUR-E (Phuleshwar), CUR-F (Prabha), CUR-G (Bawdhan), CUR-H (Pachwad), geographic or ecological variations but because of their skin conditioning is mentioned in Ayurveda. Also the

CUR-I (Alleppey), CUR-J (Kuchipudi), and CUR K (Rajampeth). The samples were harvested, cleaned under running tap water to remove soil and dirt, before bringing it to laboratory.

The rhizomes were air-dried at room temperature $\left(28 \pm 5^{\circ}\right)$ until steady weight was observed. The material was then ground to fine powder in a laboratory grinder. One percent extract was prepared by dissolving $1 \mathrm{~g}$ plant powder in $100 \mathrm{ml}$ methanol by keeping it for $24 \mathrm{~h}$. The extracts were filtered, re-volumized and passed through $0.2 \mu \mathrm{m}$ nylon filters. The extracts were stored at $-4^{\circ}$ until use.

All solvents and chemicals used during the study were of HPLC grade. HPLC grade zerumbone $(\geq 98.0 \%$ pure) was obtained from Sigma-Aldrich, Mumbai, India. An accurately weighed standard zerumbone was dissolved in known amount of methanol to obtain $\mathrm{mg} / \mathrm{ml}$ concentration of stock. The stock solution was diluted to obtain desired working concentrations $(2,10$, $25,50,100,200 \mu \mathrm{g} / \mathrm{ml})$.

The RP-HPLC analysis was performed on a chromatographic system consisting of a quaternary pump, manual injector and dual $\lambda U V$ absorbance diode array detector. The built-in chromatographic software system was used for data processing. Chromatographic separation was achieved on a Luna, C18 (5 $\mu \mathrm{m})$ reversed-phase column $(150 \times 4.6 \mathrm{~mm}, 5 \mu)$. Mobile phase consisting of acetonitrile, methanol and $0.01 \mathrm{M}$ potassium dihydrogen orthophosphate $(25: 55: 20)$ was used for separation with injection volume $20 \mu 1$. The flow rate was $1 \mathrm{ml} / \mathrm{min}$ and the detection wavelength was set to $254 \mathrm{~nm}^{[34]}$. The analysis time was $10 \mathrm{~min}$ for both standards and samples.

The validation parameters such as accuracy, precision, limit of detection (LOD), limit of quantification (LOQ), linearity, range and system suitability test were assessed by three replicate injections of standards at appropriate concentrations. The results were subjected to statistical analysis and are represented as mean $\pm \mathrm{SD}$ of three independent injections unless mentioned.

This is an open access article distributed under the terms of the Creative Commons Attribution-NonCommercial-ShareAlike 3.0 License, which allows others to remix, tweak, and build upon the work non-commercially, as long as the author is credited and the new creations are licensed under the identical terms

Accepted 12 October 2018

Revised 04 April 2018

Received 27 March 2017

*Address for correspondence

E-mail: drpaisr@gmail.com

November-December 2018

Indian Journal of Pharmaceutical Sciences 
www.ijpsonline.com

TABLE 1: DISTRIBUTION OF ZERUMBONE IN MEMBERS OF FAMILY ZINGIBERACEAE

\begin{tabular}{|c|c|c|c|c|c|}
\hline Species & Part & Content (\%) & Method & Location & Reference \\
\hline Alpinia galangal & $\mathrm{Rh}$ & 44.80 & GC-MS & Sri lanka & [5] \\
\hline Curcuma amada & $\mathrm{Rh}$ & 00.20 & GC-MS & India & [6] \\
\hline \multirow[t]{4}{*}{ C. longa } & $\mathrm{Rh}$ & NM & GC-MS & Serbia & [7] \\
\hline & SP & NM & GC-MS & China & [8] \\
\hline & $\mathrm{Rh}$ & NM & GC-MS & Pakistan & [9] \\
\hline & $\mathrm{Rh}$ & NM & GC-FID & Brazil & [10] \\
\hline C. longa cv ROMA & Rh, L & NM & GC-MS & India & [11] \\
\hline C. longa cv Selam & $\mathrm{Rh}$ & $0.22 / 0.57$ & RP-HPLC & India & Present study* \\
\hline C. longa cv Krishna & $\mathrm{Rh}$ & $0.08 / 0.45$ & & & \\
\hline C. longa cv Tekur & $\mathrm{Rh}$ & $0.15 / 0.32$ & & & \\
\hline C. longa cv Rajapuri & $\mathrm{Rh}$ & $0.13 / 0.37$ & & & \\
\hline C. longa cv Phuleshwar & $\mathrm{Rh}$ & $0.12 / 0.36$ & & & \\
\hline C. longa cv Prabha & $\mathrm{Rh}$ & $0.10 / 0.45$ & & & \\
\hline C. longa cv Bawdhan & $\mathrm{Rh}$ & $0.04 / 0.64$ & & & \\
\hline C. longa cv Pachwad & $\mathrm{Rh}$ & $0.13 / 0.42$ & & & \\
\hline C. longa cv Alleppey & $\mathrm{Rh}$ & $0.16 / 0.83$ & & & \\
\hline C. longa cv Kuchipudi & $\mathrm{Rh}$ & $0.10 / 0.35$ & & & \\
\hline C. longa cv Rajampeth & $\mathrm{Rh}$ & $0.20 / 0.61$ & & & \\
\hline C. purpurascens & $\mathrm{Rh}$ & NM & GC-MS & Indonesia & [12] \\
\hline C. zedoaria & $\mathrm{Rh}$ & $N M$ & GC & Vietnam & [13] \\
\hline Xylopia aetiopica & $\mathrm{Fr}$ & 04.00 & GC-MS & Nigeria & [14] \\
\hline Zingiber aromaticum & $\mathrm{Rh}$ & 17.72 & GC-MS & Malaysia & [15] \\
\hline Z. cassumunar & $\mathrm{Rh}$ & 01.00 & GC-MS & India & [16] \\
\hline Z. montanum & $\mathrm{Rh}$ & 02.00 & Spec. & Bangladesh & [17] \\
\hline Z. officinale & $\mathrm{Rh}$ & 36.98 & GC-MS & Bangladesh & [18] \\
\hline Z. ottensii & $\mathrm{Rh}$ & 25.60 & GC-MS & Malaysia & [19] \\
\hline Z. spectabile & $\mathrm{Rh}$ & 59.10 & GC-MS & Malaysia & [20] \\
\hline \multirow[t]{11}{*}{ Z. zerumbet } & $\mathrm{Rh}$ & $76.30-84.80$ & GC-MS & India & [21] \\
\hline & $\mathrm{Rh}$ & 01.81 & HPTLC & India & [22] \\
\hline & $\mathrm{R}$ & 00.16 & & & \\
\hline & L & 00.09 & & & \\
\hline & $\mathrm{Fl}$ & 00.03 & & & \\
\hline & $\mathrm{Rh}$ & 68.90 & GC-MS & Malaysia & [21] \\
\hline & $\mathrm{Rh}$ & 00.11 & & Malaysia & [23] \\
\hline & $\mathrm{Rh}$ & 65.30 & GC-MS & Tahiti island & [24] \\
\hline & $\mathrm{Rh}$ & 72.30 & GC-MS & Vietnam & [25] \\
\hline & $\mathrm{Rh}$ & 37.00 & GC-MS & France & [26] \\
\hline & $\mathrm{L}$ & 00.40 & GC-MS & France & \\
\hline
\end{tabular}

Rh: Rhizome, R: root; S: stem; L: leaf; Fl: flower; Fr: fruit; SP: sample powder; Spec.: spectroscopy; *content in present study represented as fresh wt./dry wt. basis

Accuracy of the method was determined by recovery analysis of the known amounts of standard zerumbone $(2,10,50 \mu \mathrm{g} / \mathrm{ml})$ added to a placebo sample. The samples were analysed ( 3 replicates) and the amounts were calculated from the calibration curve. The recovery was presented in percent accuracy (calculated concentration/nominal concentration $\times 100$ ) and it ranged from 98.60 to $100.63 \%$ indicating acceptable range as per $\mathrm{ICH}$ recommendations for the given method $^{[35]}$.

Precision of the method was measured according to $\mathrm{ICH}$ recommendations ${ }^{[35]}$. Three injections of zerumbone at three different concentrations $(2,10,50 \mu \mathrm{g} / \mathrm{ml})$ showed excellent repeatability (intra-day precision), and relative standard deviation (RSD) was within $3.76 \%$. Inter-day precision was determined by measuring 
intra-day variation for triplicated determination of the same standard zerumbone concentrations $(2,10$, $50 \mu \mathrm{g} / \mathrm{ml}$ ). The lower RSD values indicated the acceptable reproducibility of the method.

The LOD and LOQ were calculated based on the signal:noise ratio. The LOD for zerumbone was $0.04 \mu \mathrm{g} / \mathrm{ml}$ and LOQ was $0.12 \mu \mathrm{g} / \mathrm{ml}$ using above chromatographic injections. The system suitability test was performed for the above chromatographic system used for analysis. This was performed before sample analysis to pass the system suitability limits. The evaluation was done using standard zerumbone $200 \mu \mathrm{g} / \mathrm{ml}$ concentration. The capacity factor ( $k$ ') was 0.711 indicating that the zerumbone peak is well resolved with respect to the void volume. The tailing factor $(\mathrm{T})$ for zerumbone peak was 1.332 , reflecting good peak symmetry. The resolution (Rs) for the principle peak was 1.026, indicating good separation of the analytes. The theoretical plate number (n) was 1202.95 for the column used in the study $(150 \times 4.6 \mathrm{~mm}$ i.d., particle size $5 \mu \mathrm{m}$ ), thus demonstrating acceptable column efficiency. The RSD of three consecutive injections of $10 \mu \mathrm{g} / \mathrm{ml}$ concentration of zerumbone was $0.707 \%$, indicating fair injection repeatability. All these results assure the adequacy of the method for analysis of zerumbone in C. longa.

The linear regression data for the calibration plots showed a good linear relationship over a six concentration range from 2 to $200 \mu \mathrm{g} / \mathrm{ml}$ for zerumbone with respect to the peak areas. It was observed from the data that, the linearity response of zerumbone is linear between lower to higher concentration levels (fig. 1 and 2A). Regression Eqn. was obtained using least-square method and the standard deviation did not exceed $2 \%$ level.

Six different concentrations $(2,10,25,50,100$ and $200 \mu \mathrm{g} / \mathrm{ml}$ ) of standard zerumbone were detected at $254 \mathrm{~nm}$ wavelength using RP-HPLC technique. The analysis yielded profiles with a retention time of $5.735 \pm 0.28 \mathrm{~min}$ (fig. 2A). The linearity and sensitivity of the method was analysed using the set conditions, three independent calibration curves for the compound was plotted correlating the detector signals with concentrations of zerumbone (fig. 1). Linear calibration curves for standards were obtained with coefficient of determination $\left(R^{2}\right)$ not more than 0.999 for standard zerumbone (fig. 1). Results of placebo and blank were also recorded for the study (fig 2B and C).
The applicability of the present method was analysed using eleven cultivars of $C$. longa. The extracts obtained from fresh and dry rhizomes of eleven C. longa cultivars were subjected to the analysis. The zerumbone content determined using RP-HPLC method ranged from $0.383 \pm 0.019 \mathrm{mg} / \mathrm{g}$ (CUR-G) to $2.179 \pm 0.109 \mathrm{mg} / \mathrm{g}$ (CUR-A) on fresh weight basis and from $3.209 \pm$ $0.160 \mathrm{mg} / \mathrm{g}$ (CUR-C) to $8.333 \pm 0.417 \mathrm{mg} / \mathrm{g}$ (CUR-I) on dry weight basis (fig. 2D, E and F). This range was within the content observed in other species earlier studied from the same family (Table 1). Members of genus Curcuma showing lower zerumbone content compared to Zingiber, Alpinia and Xylopia species (Table 1). However, the present study showed higher zerumbone content in different cultivars of $C$. longa.

Of the eleven-accession evaluated for zerumbone content, Selam accession (CUR-A) yielded higher on fresh weight basis whereas, Alleppey accession (CUR-I) was higher on dry weight basis (fig. 3). It should be noted here that the lowest content on dry weight basis is equal to or more than the highest content obtained in fresh weight basis (fig. 3). The percent differences between the two in all the eleven cultivars were $\geq 50 \%$. Accession CUR-G had showed a higher percent difference of $92 \%$ in content from fresh and dry weighed extracts followed by CUR-B (81 \%), CUR-I (79 \%) and CUR-F (75\%) with $\geq 70 \%$ difference.

The content observed in C. longa cultivars in present study is comparatively less than that of earlier reports from $Z$. zerumbet (Table 1). The content observed hereto in the literature are based on gas chromatography-mass spectrometry analysis, our result presents for the first time a validated RP-HPLC method for quantifying zerumbone from $C$. longa, especially different cultivars. These cultivars represent the agroclimatic regions of their cultivation in India and can also suggest its utilization in that respective region. Such study can

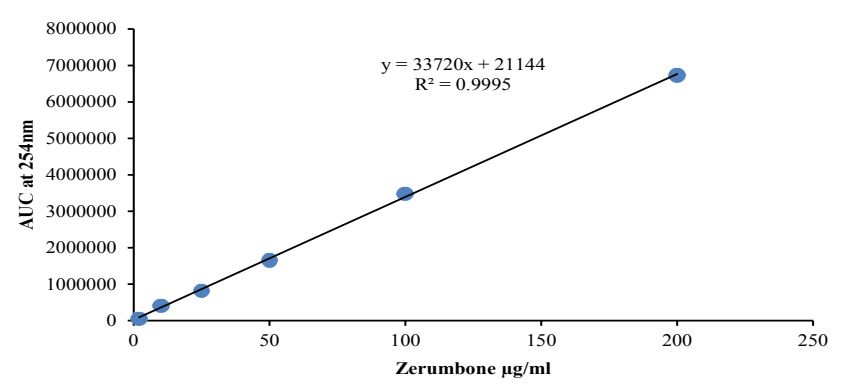

Fig. 1: Calibration curve of standard zerumbone

Six point calibration curve of standard zerumbone at concentrations of $2,10,25,50,100$ and $200 \mu \mathrm{g} / \mathrm{ml}$ 

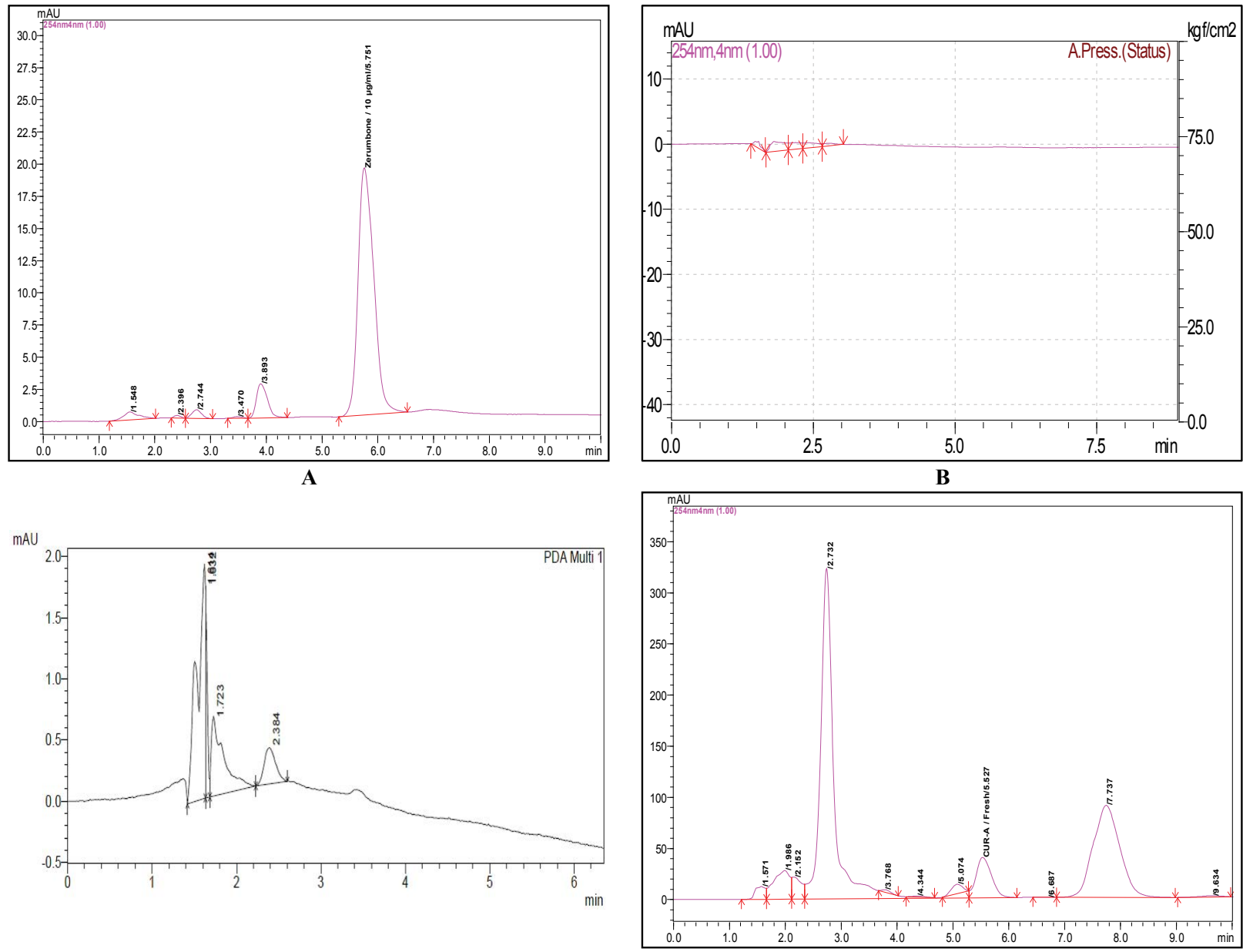

C.

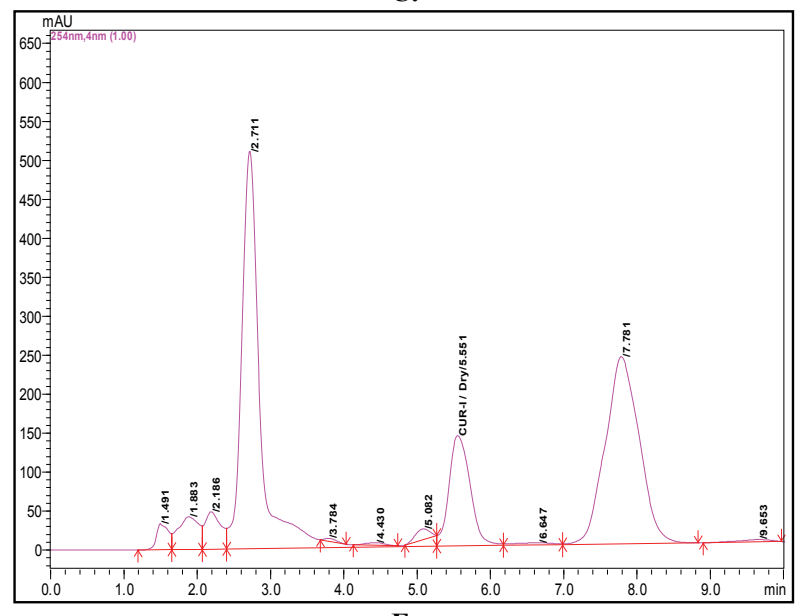

D.

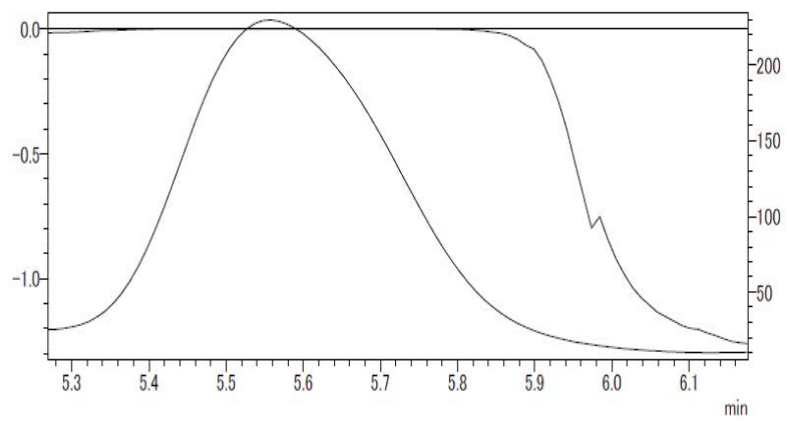

F.

Fig. 2: RP-HPLC profiles

(A) Standard zerumbone $10 \mu \mathrm{g} / \mathrm{ml}$, (B) RP-HPLC profile of blank, (C) RP-HPLC profile of placebo, (D) fresh rhizome sample of $C$. longa accession CUR-A, (E) dry sample of $C$. longa accession CUR-A and (F) purity curve of sample $C$. longa accession CUR-I

provide a data to compare use of high yielding C. longa cultivars to the risk of related diseases.

The study provides comprehensive information on zerumbone content in members of family Zingiberaceae. The validated method for quantification of zerumbone could be used consistently with greater reliability. Among the $C$. longa cultivars, Alleppey (CUR-I) followed by Bawdhan (CUR-G), Rajampeth (CUR-K) and Selam (CUR-A) had zerumbone content over $0.5 \%$. This is in the lights of further pharmacological utility of these cultivars. 


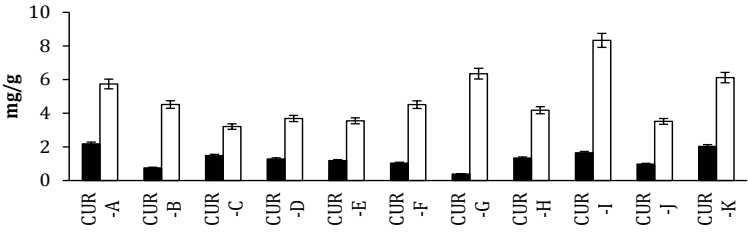

Fig. 3: Zerumbone content in fresh and dry rhizomes of $C$. longa cultivars

Comparative histograms of zerumbone content in $\mathrm{mg} / \mathrm{g}$ in fresh and dry rhizomes of $C$. longa cultivars. ( $\square$ ) Fresh and ( $\square$ ) dry

\section{Acknowledgements:}

Authors thank the Director, AIB, Amity University, Mumbai, HOD, Biotechnology and HOD, Botany, Shivaji University, Kolhapur for their support. Thanks are also due to Dr Jaykumar Chavan, Department of Botany, YCIS, Satara, India for gifting standard zerumbone. NVP is indebted to the Principal and HOD, Department of Botany, The New College, Kolhapur.

\section{Conflict of interest:}

There is no conflict of interest, financial or otherwise associated with this project.

\section{REFERENCES}

1. Murakami A, Takahashi D, Kinoshita T, Koshimizu K, Kim HW, Yoshihiro A, et al. Zerumbone, a Southeast Asian ginger sesquiterpene, markedly suppresses free radical generation, proinflammatory protein production, and cancer cell proliferation accompanied by apoptosis: the alpha, betaunsaturated carbonyl group is a prerequisite. Carcinogenesis 2002;23:795-802.

2. Rahman HS, Rasedee A, Yeap SK, Othman HH, Chartrand MS, Namvar F, et al. Biomedical properties of a natural dietary plant metabolite, Zerumbone, in Cancer therapy and chemoprevention trials. BioMed Res Int 2014;2014:920742.

3. Tzeng T, Liou S, Chang CJ, Liu I. Zerumbone, a tropical ginger sesquiterpene, ameliorates streptozotocin-induced diabetic nephropathy in rats by reducing the hyperglycemiainduced inflammatory response. Nutr Metab 2013;10:64-6.

4. Yob NJ, Jofrry SM, Affandi MMR, Teh LK, Salleh MZ, Zakaria ZA. Zingiber zerumbet (L.) Smith: a review of its ethnomedicinal, chemical, and pharmacological uses. Evid Based Complement Alternat Med 2011;2011:543216.

5. Arambewela LSR, Arawwawala M, Owen NL, Jarvis B. Volatile oil of Alpinia galanga willd. of Sri Lanka". J Essent Oil Res 2007;19:455-6.

6. Srivastava AK, Srivastava SK, Shah N. Constituents of the rhizome essential oil of Curcuma amada Roxb. From India. J Essent Oil Res 2001;13:63-4.

7. Stanojević JS, Stanojević LP, Cvetković DJ, Danilović BR. Chemical composition, antioxidant and antimicrobial activity of the turmeric essential oil (Curcuma longa L.). Adv Technol 2015:4;19-25.

8. Lu D, Cao Y, Li L, Zhu Z, Dong X, Zhang H, et al. Comparative analysis of essential oils found in Rhizomes Curcumae and
Radix Curcumae by gas chromatography-mass spectrometry. J Pharm Anal 2011;1(3):203-7.

9. Naz S, Ilyas S, Parveen Z, Javed S. Chemical analysis of essential oils from turmeric (Curcuma longa) rhizome through GC-MS. Asian J Chem 2010;22:3153-8.

10. Braga ME, Leal PF, Carvalho JE, Meireles MA. Comparison of yield, composition, and antioxidant activity of turmeric (Curcuma longa L.) extracts obtained using various techniques. J Agric Food Chem 2003;51:6604-1.

11. Raina VK, Srivastava SK, Jain N, Ahmad A, Syamasundar $\mathrm{KV}$, Aggarwal KK. Essential oil composition of Curcuma longa L. cv. Roma from the plains of northern India. Flavour Fragr J 2002; 17:99-102.

12. Hong SL, Lee GS, Rahman SNSA, Hamdi OAA, Awang $\mathrm{K}$, Nugroho NA, et al. Essential oil content of the rhizome of Curcuma purpurascens Bl. (Temu Tis) and its antiproliferative effect on selected human carcinoma cell lines. ScientificWorldJournal 2014;2014:397430.

13. Giang PM, Son PT, Jin HZ, Lee JH, Lee JJ. Comparative study on inhibitory activity of zerumbone and zerumbone 2,3-epoxide on NF- $\kappa$ B activation and NO production. Sci Pharm 2009;77:589-95.

14. Ogunwande IA, Olawore ON, Adeleke KA. Contribution to the study of essential oil of Xylopia aethiopica (DUNAL) A. RICH: isolation and characterization of zerumbone. J Essent Oil Bear Pl 2005;8:159-64.

15. Muhammad AMS. A study on microwave-assisted extraction of Zingiber aromaticum [dissertation]. Pahang, Malaysia: University of Malaysia; 2009.

16. Kishore N, Dwivedi RS. Zerumbone: a potential fungitoxic agent isolated from Zingiber cassumunar Roxb. Mycopathologia 1992;120:155-9.

17. Al-Amin M, Sultana GNN, Hossain CF. Antiulcer principle from Zingiber montanum. J Ethnopharmacol 2012;141:57-60.

18. Bhuiyan NI, Chowdhury JU, Begum J. Chemical investigation of the leaf and rhizome essential oils of Zingiber zerumbet (L.) Smith from Bangladesh. Bangladesh J Pharmacol 2009;4:9-12.

19. Sirat HM and Nordin AB. Essential oil of Zingiber ottensii Valeton. J Essent Oil Res 1994;6:635-6.

20. Sivasothy Y, Awang K, Ibrahim H, Thong KL, Fitrah N, Koh $\mathrm{XP}$, et al. Chemical composition and antibacterial activities of essential oils from Zingiber spectabile Griff. J Essent Oil Res 2012;24:305-13.

21. Baby S, Dan M, Thaha ARM, Johnson AJ, Kurup R, Balakrishnapillaia $\mathrm{P}$, et al. High content of zerumbone in volatile oils of Zingiber zerumbet from Southern India and Malaysia. Flavour Fragr J 2009;24:301-8.

22. Rout KK, Mishra SK, Sherma J. Development and validation of an HPTLC method for analysis of zerumbone, the anticancer marker from Zingiber zerumbet. Acta Chromatogr 2009;21:443-52.

23. Rasedee A, Heshu SR, Bustamam A, How CW, Swee KY. A composition for treating leukaemia. Malaysian Patent Application No: PI2013700213. 2013.

24. Lechat-Vahirua I, Francois P, Menut C, Lamaty G, Bessiere JM. Aromatic plants of French Polynesia. I. Constituents of the essential oils of rhizomes of three Zingiberaceae: Zingiber zerumbet Smith, Hedychium coronarium Koenig and Etlingera cevuga Smith. J Essent Oil Res 1993;5:55-9. 
25. Dung NX, Chinh TD, Rang DD, Leclercq PA. The constituents of the rhizome oil of Zingiber zerumbet (L.) Sm. from Vietnam. J Essent Oil Res 1993;5:553-5.

26. Chane-Ming J, Vera R, Chalchat JC. Chemical composition of the essential oil from rhizomes, leaves and flowers of Zingiber zerumbet Smith from Reunion Island. J Esseni Oil Res 2003;15:202-5.

27. Sasikumar B. Genetic resources of Curcuma: Diversity characterization and utilization. Plant Genet Resour 2005;3:230-51.

28. Velayudhan KC, Dikshit N, Nizar AM. Ethnobotany of turmeric (Curcuma longa L.). Indian J Tradit Know 2012;11:607-14.

29. Khare CP. Indian Medicinal Plants. New York, USA: SpringerVerlag; 2007.

30. Gantait A, Barman T, Mukerjee PK. Validated method for estimation of curcumin in turmeric powder. Indian $\mathrm{J}$ Tradit Know 2011;10:247-50.
31. Chattopadhyay I, Biswas K, Bandyopadhyay U, Banerjee RK. Turmeric and curcumin: Biological actions and medicinal applications. Curr Sci 2004;87:44-53.

32. Jurenka JS. Anti-inflammatory properties of curcumin, a major constituent of Curcuma longa: A review of preclinical and clinical research. Altern Med Rev 2009;14:141-53.

33. Akram M, Shahab-Uddin, Ahmed A, Khan U, Hannan A, Mohiuddin E, et al. Curcuma longa and curcumin: A review article. Romanian J Biol-Plant Biol 2010;55:65-70.

34. Eid EEM, Abdul AB, Al-Zubairi AS, Sukari MA, Abdullah R. Validated high performance liquid chromatographic (HPLC) method for analysis of zerumbone in plasma. Afr $\mathrm{J}$ Biotech 2010;9(8):1260-5.

35. ICH Guideline: Q2 (R1): Validation of analytical procedure: Text and Methodology. Available from: https://www.ich. org/fileadmin/Public_Web_Site/ICH_Products/Guidelines/ Quality/Q2_R1/Step4/Q2_R1_Guideline.pdf. 